\title{
Evaluation of Direct Application of Enzymes to Remediate Soil Water Repellency
}

\author{
Lusheng Zeng \\ Crop and Soil Sciences, University of Georgia, Griffin Campus, 1109 \\ Experiment Street, Weed Science Building, Griffin, GA 30223-1797; and \\ the College of Resource and Environment, Qingdao Agricultural \\ University, Qingdao 266109, China
}

\section{Jiayang Liu \\ Fermentation Technology Division, School of Bioengineering, Huanghuai University, Zhumadian 463000, China}

\author{
Robert N. Carrow ${ }^{1}$, Paul L. Raymer, and Qingguo Huang \\ Crop and Soil Sciences, University of Georgia, Griffin Campus, 1109 \\ Experiment Street, Weed Science Building, Griffin, GA 30223-1797
}

Additional index words. localized dry spot, turfgrass, WDPT (water drop penetration time)

\begin{abstract}
Organic coatings on sand particles can cause soil water repellency (SWR) where a soil does not spontaneously wet; this leads to challenges in water management and crop production. In laboratory studies, we evaluated a novel approach using direct application of 10 enzymes at three (low, medium, high) dosages to remediate SWR on two sand turfgrass soils in a 3-day incubation study and a second study at high dosage with 1-day incubation. A soil:solution ratio of $1: 1(10 \mathrm{~g}$ soil and $10 \mathrm{~mL}$ solution) was used and a deionized water control included. For Soil 7 , a very strongly hydrophobic soil from a localized dry spot turfgrass area with a water drop penetration time (WDPT) of 7440 seconds (untreated) and 332 to 338 seconds (water-treated), the high dosage rates of laccase, chitinase, and protease at 1 and 3 days incubation resulted in WDPT of less than 60 seconds (i.e., hydrophilic soil). Pectinase exhibited similar results only in the 3-day incubation study. On the strongly hydrophobic Soil 21 (WDPT of 655 seconds untreated; 94 to 133 water-treated) from the dry area of a fairy ring-affected area on a turfgrass site, high dosages of chitinase, laccase, pectinase, and protease reduced WDPT to less than 60 seconds in both studies; and medium dosage rates were also effective for all but protease in the 3-day incubation study. Each of the four most effective enzymes for reducing WDPT, noted previously, demonstrated a significant exponential or logarithmic relationship between decreasing WDPT and increasing enzyme dosage. Further studies in field situations will be required to determine enzyme effectiveness on SWR and water management.
\end{abstract}

Soil water repellency (SWR) is a condition in which a soil does not spontaneously wet when a drop of water is applied to the surface, indicating that the soil is hydrophobic (Müller and Deurer, 2011). In recent years there has been greater attention to SWR as a result of increased awareness of its negative implications, especially on water management and associated environmental issues, which include reduced soil water intake, uneven wetting patterns, reduced irrigation efficiency and effective precipitation infiltration, increased preferential flow that may affect aquifer contamination, increased runoff and erosion,

Received for publication 10 Dec. 2013. Accepted for publication 18 Feb. 2014.

The study was supported in part by HATCH funds and a grant from Technology Commercialization Office, University of Georgia Research Foundation, Athens, GA

${ }^{1}$ To whom reprint requests should be addressed; e-mail rcarrow@uga.edu. limited seed and vegetative establishment, and reduced plant growth and quality (Dekker et al., 2005; Doerr et al., 2000; Müller and Deurer, 2011).

Hydrophobic soils are found in many countries on traditional and no-till agricultural soils, pastures, coastal dune sands, shrub lands, parks, turfgrass soils, greenhouse potting media, fire-induced SWR in forestlands, and soils irrigated with treated wastewater (Bailey et al., 2012; Barton and Colmer, 2011; Blanco-Canqui, 2011; Fidanza et al., 2007; Müller and Deurer, 2011; Nadav et al., 2011). Roper (2005) reported SWR occurring on more than 5 million hectares of western and southern Australia. Patterns of SWR differ with the field situation. On sandy turfgrass soils and grasslands, SWR is a recurring problem, where the normal situation is called "localized dry spot" (LDS) or dry patch, and SWR appears as irregular dry areas from a few centimeters to several meters diameter with the repellency usually extending from the surface to 5 to $10 \mathrm{~cm}$ depth (Doerr et al., 2000). A second SWR situation on turfgrass sites is within the dry area of basidiomycete induced "fairy ring" on all soil types (Barton and Colmer, 2011; Fidanza et al., 2007).

Although SWR can occur in diverse climates and soils, it is most prevalent on sandy soils, which have low particle-surface area compared with soils higher in silt and clay content and sands are more prone to surface drying (Müller and Deurer, 2011). On sand soils, SWR is universally attributed to hydrophobic organic matter coating on the sand particle surfaces and hydrophobic organic particulate matter from plant debris or added as an amendment, whereas high organic matter in the thatch/mat layer may also contribute (Barton and Colmer, 2011; Franco et al., 1995; Müller and Deurer, 2011). For fine-textured soils exhibiting SWR, organic coatings are on soil aggregate surfaces. The sources of organic matter contributing to hydrophobic organic coatings are diverse and may include waxes, fatty acids, and lignin (a recalcitrant polymer of phenols) from plant leaves and other decomposing organic matter, plant root exudates, fungal hyphae/exudates, volatile organic compounds that condense on soil particles following forest or grassland fires, and organic matter in wastewater (Atanassova and Doerr, 2010). Regardless of soil type or organic matter source, soil drying increases repellency with air-drying greatly enhancing SWR severity (Müller and Deurer, 2011).

Many scientists have studied the chemical nature of the organic matter coatings, but there has been limited success in identification of specific compounds (Atanassova and Doerr, 2010). The generic types of organic compounds suggested to be involved with SWR include: 1) high-molecular-weight, polar fatty acids and their esters are the most often reported as contributing to hydrophobic coatings where these are alkanes-derived from plant and cuticular waxes; 2) other alkanes (paraffin-like compounds), microbial-derived waxes, alkanols, phytanols, and phytanes; 3 ) amphiphilic (partially hydrophobic) lipids, stigmasterols, and plant-derived sterols that have polar (hydrophilic) and non-polar (hydrophobic) groups; 4) other polar molecules such as sugars, glycosides, aromatic acids, and low-molecular-weight organic acids; 5) humic and fulvic acids from soil microbial activity or possibly added as amendments; and 6) hydrophobins and cysteine-rich proteins expressed only by filamentous fungi (Atanassova and Doerr, 2010; Doerr et al., 2005; Rillig, 2005). Difficulty in determining the nature of specific organic coatings may be the result of: 1) thin coatings of even a single layer on sand surfaces to small globules of organic matter on sand surfaces that are difficult to see even in scanning electron micrography or to selectively extract by chemical means; 2) changes occur in the orientation and hydrophobichydrophilic nature of compounds during drying and wetting but not the chemical composition; and 3) the extraction challenges presented by the complexity and diversity of various soil organic matter compounds present 
(Atanassova and Doerr, 2010; Doerr et al., 2000; Horne and McIntosh, 2000).

Müller and Deurer (2011) reviewed 12 SWR remediation strategies reported in the literature and noted that even with the major increase in SWR research over the past decade, current remediation strategies are limited in effectiveness. Application of wetting agents (surfactants) has been the most effective remediation practice, probably because it is focused on altering the hydrophobic organic matter properties and surface tension of water. However, this approach is costly and only renders short-term positive effectiveness with repeated applications needed to maintain hydrophilic conditions (Moore et al., 2010; Müller and Deurer, 2011). Biological methods involving culturing microorganisms capable of degrading wax in soil is another remediation approach that concentrates on altering the nature of the organic matter associated with SWR and it has been shown to be effective at the laboratory scale (Müller and Deurer, 2011; Roper, 2004). However, limitations exist in practical field applications such as costs and maintaining viable inoculation population levels (Roper, 2005, 2006).

Sidhu et al. (2012, 2013) applied laccase directly to turfgrass ecosystems and induced decomposition of organic matter in the thatch/ mat, which were the first reports of success using direct enzyme applications of specific enzymes. Our hypothesis is that application of enzymes might directly alter or degrade the diverse organic materials contributing to SWR in a manner to reduce their hydrophobic nature and offer a new management option to this difficult field problem. In a laboratory study, Liu et al. (2013b) were the first to use this novel approach on SWR soils by applying enzymatic coproducts (mainly laccase mixed with other trace enzymes) from a biofuel research project on fungal pretreatment of switchgrass (Panicum virgatum) for improved saccharification to eight air-dried SWR soils from several golf courses with WDPT of 345 to $7439 \mathrm{~s}$. All treated soils exhibited a WDPT of less than $60 \mathrm{~s}$ and the observed decrease in WDPT was positively related to the increased enzyme activity level for each soil in an exponential or logarithmic relationship.

Based on the results observed by Liu et al. (2013b) with application of laccase to remediate SWR, additional proof-of-concept laboratory studies were conducted with the following objectives: 1) to evaluate the effectiveness of 10 diverse enzymes directly applied on two SWR soils at three dosages using a 3-d incubation to remediate SWR; and 2) to investigate the most effective enzymes in the initial study on the same soils but using a 1-d incubation period.

\section{Materials and Methods}

Soils and enzymes. The two soils used in all three experiments are described in Table 1. Samples were obtained in Feb. 2012 from the surface 0 to $3.8 \mathrm{~cm}$ within areas exhibiting field SWR symptoms using a soil profiler sampler and collecting $\approx 8 \mathrm{~L}$ volume of soil from four to six sites within an area. Soil 7 was from a golf course rough planted to 'Salam' seashore paspalum (Paspalum vagnitum $\mathrm{O}$. Swartz) exhibiting normal localized dry spot, whereas Soil 21 was collected from the SWR zone of a fairy ring on a 'Tifdwarf' bermudagrass [Cynodon dactylon (L.) Pers. $\times$ C. transvaalensis Burtt Davy] golf green. These soils were selected based on exhibiting a consistent and high degree of SWR for normal LDS (Soil 7) and fairy ring (Soil 21) in the field and as confirmed by Liu et al. (2013b). Soils were air-dried at room temperature for several days, gently passed through a $2-\mathrm{mm}$ sieve to remove grass debris, and then stored at room temperature.
Enzymes were selected to allow activity on a diversity of organic matter substrates that have been reported to be present in the SWR organic fraction; and the nature of organics in both soils was not known and could differ between soils (Table 2). All enzymes used in this study except laccase were newly purchased from Sigma-Aldrich (St. Louis, MO) and their enzyme activity based on the SigmaAldrich product claim. Laccase was produced by the method of Liu et al. (2013a) using the white-rot fungus Pycnoporus sp. SYBC-L3 (18S rRNA sequence deposited in GenBank with an accession number GU182936) from stock culture stored at the Key Laboratory of Industrial Biotechnology, Ministry of Education, School of Biotechnology, Jiangnan University, Wuxi, China. This culture was stored on full-strength potato dextrose agar slants at $4{ }^{\circ} \mathrm{C}$ in a refrigerator and periodically (usually every 4 weeks) transferred to maintain activity. This fungus has shown potential for high laccase production in deep liquid fermentation at the reactor scale and its extracellular proteins have been partially identified (Liu et al., 2013a). Activity of laccase was determined based on the 2,6dimethylphenol (DMP) method described by Park et al. (1999) with some modification. In detail, a $3 \mathrm{~mL}$ reaction mixture $(2.4 \mathrm{~mL}$ citrate phosphate buffer $/ \mathrm{pH} 3.5,0.1 \mathrm{M} ; 0.1 \mathrm{~mL}$ enzyme solution; $0.5 \mathrm{~mL} \mathrm{DMP} / 10 \mathrm{~mm}$ ) was prepared at room temperature. The oxidation was estimated by absorbance at $469 \mathrm{~nm}(\varepsilon=$ $49.5 \mathrm{~mm}^{-1} \cdot \mathrm{cm}^{-1}$ ) and one unit of activity was defined as the amount of enzyme that oxidized $1 \mu \mathrm{mol}$ of DMP per minute. Each enzyme solution was divided into low dosage, medium dosage, and high dosage with the dosage designation for Sigma source enzymes based solely on enzyme activity available from Sigma and not on any reported agronomic response. Laccase dosages were based on results of Sidhu et al. $(2012,2013)$ in their

Table 1. Description of soil sample locations on golf courses with sample depth, site use, grass type, and type of soil water repellency of the two soils used in the studies. $^{z}$

\begin{tabular}{|c|c|c|c|c|c|}
\hline Soil no. & Description & Depth $(\mathrm{cm})$ & Location & Comments & WDPT $(s)^{y}$ \\
\hline 7 & Rough 10,10 years old, Salam Paspalum vaginatum & $0-3.8$ & Old Collier GC, Naples, FL & Sand area, normal LDS & $7440 \pm 20$ \\
\hline
\end{tabular}

${ }^{\mathrm{z}}$ Both were sand soils with greater than $97 \%$ sand by dry weight sieve analysis.

${ }^{\mathrm{y}}$ Based on three replications with standard deviation noted.

LDS = localized dry spot; Water droplet penetration time (WDPT, $s$ ) is for soils before treatment with any enzymes or water control.

Table 2. Description of enzymes used in this study. ${ }^{2}$

\begin{tabular}{|c|c|c|c|c|}
\hline \multirow[b]{2}{*}{ Enzymes } & \multirow[b]{2}{*}{ Sources description } & \multicolumn{3}{|c|}{ Dosage (units/g soil) } \\
\hline & & Low & Medium & High \\
\hline Cellulase & From Aspergillus niger, $1.2 \mathrm{U} / \mathrm{mg}$ solid & 3 & 15 & 75 \\
\hline$\beta$-Glucosidase & From almonds, $2 \mathrm{U} / \mathrm{mg}$ or greater & 0.03 & 0.3 & 3 \\
\hline Laccase & From Pycnoporus sp. SYBC-L3, $5.3 \mathrm{U} / \mathrm{mL}$ & 0.08 & 0.8 & 8 \\
\hline Lipase & From Aspergillus niger, $181 \mathrm{U} / \mathrm{g}$ & 0.003 & 0.027 & 0.27 \\
\hline Xylanase & From Thermomyces lanuginosus, $2500 \mathrm{U} / \mathrm{g}$ or greater; recombinant, expressed in Aspergillus oryzae & 0.375 & 3.75 & 37.5 \\
\hline
\end{tabular}

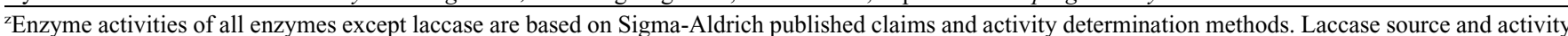
determination method are described in the "Materials and Methods." 
studies on organic matter decomposition in thatch/mat.

Experimental design. In the first laboratory study, the two SWR soils were treated with 10 enzymes at three dosage rates for a 3-d incubation along with a deionized water control to assess enzyme effects on SWR using the WDPT (Tables 1 and 2). In the second laboratory study, the four most effective enzymes from the first study in alleviation of SWR based on the WDPT data were evaluated at the high dosage using a 1-d incubation on both soils to provide insight on consistency of response and timeframe for enzyme activity. A randomized complete block design was used in both investigations with a deionized water control included. Analysis of variance (ANOVA) was performed for each soil separately to evaluate the main effects of enzyme type and dosage in the first experiment and for enzyme effect in the second study using the general linear model (GLM; SAS Institute Inc., 1994). Fisher's protected least significant difference test with $\alpha=0.01$ was used to test statistical differences among treatment means. In the first experiment, regression analysis by soil was conducted on WDPT response relative to dosage rate (deionized water control and three enzyme rates) for those enzymes that were effective in remediating SWR [Excel 2013 Data Analysis program (Microsoft, 2013, Redmond, WA)].

Treatment of soil samples with enzymes. In each study, $10 \mathrm{~g}$ of air-dried soil was placed in a $50-\mathrm{mL}$ porcelain crucible with a soil surface area of $14.0 \mathrm{~cm}^{2}$ followed by addition of $10 \mathrm{~mL}$ enzyme solution or control (deionized water) with three replications of each treatment. The crucible was covered with parafilm after homogeneous shaking for $30 \mathrm{~min}$ and incubated under static condition at room temperature for 3 and $1 \mathrm{~d}$ with periodic shaking for $1 \mathrm{~min}$ daily at $0900 \mathrm{HR}$ for Studies 1 and 2, respectively. We used a thin needle to gently stir soils that settled down the bottom of the crucible after addition of enzyme. The treated soil samples were separated by filtration
(Grade 40, ashless, $8 \mu \mathrm{m}$ ) under vacuum conditions and oven-dried at $40{ }^{\circ} \mathrm{C}$ for $36 \mathrm{~h}$ and then subjected to WDPT analysis. The filtrate from this procedure was then analyzed for remaining laccase activity from the two soils in first experiment using the DMP method.

Analysis of soil water repellency. The degree of water repellency was analyzed using the WDPT method described by Doerr (1998). Three separate water drops $(0.05 \mathrm{~mL}$ for each) were gently placed onto the soil surface in each crucible with three crucibles per treatment combination. Penetration time was recorded by a timer with the end point being when each water drop was completely infiltrated.

\section{Results and Discussion}

Soil water repellency of untreated soil samples. Untreated soils were highly waterrepellent with the normal LDS Soil 7 exhibiting a WDPT of $7439 \mathrm{~s}$ and the fairy ring SWR Soil 21 a WDPT of $655 \mathrm{~s}$ (Table 1). The WDPT test as presented by Doerr (1998) involves placement of a droplet of water on an air- or oven-dried soil sample surface with the WDPT classes being: less than $5 \mathrm{~s}$ penetration time as very hydrophilic soil; 5 to $60 \mathrm{~s}$ hydrophilic; 60 to $180 \mathrm{~s}$ slightly hydrophobic; 180 to $600 \mathrm{~s}$ moderately hydrophobic; 600 to 3600 s strongly hydrophobic; 1 to $5 \mathrm{~h}$ very strongly hydrophobic; and greater than $5 \mathrm{~h}$ as extremely hydrophobic (Doerr, 1998). According to this standard, Soil 7 would be classified as very strongly hydrophobic and Soil 21 as strongly hydrophobic. Doerr et al. (2000) reviewed maximum WDPTs reported in the literature and noted a range of 55 to $21,600 \mathrm{~s}$. In most studies, maximum WDPTs were less than $600 \mathrm{~s}$ with few values exceeding $3600 \mathrm{~s}(1 \mathrm{~h})$; however, few tests were extended beyond $600 \mathrm{~s}$.

Incubation with deionized water for $3 \mathrm{~d}$ followed by drying at $40{ }^{\circ} \mathrm{C}$ for $36 \mathrm{~h}$ decreased WDPT 95\% (from 7439 to 338 s, moderately hydrophobic) for Soil 7 and 80\% (from 655 to $138 \mathrm{~s}$, slightly hydrophobic) for Soil 21 (Table 3). In a companion study using eight SWR soils, Liu et al. (2013b) reported an average $62 \%$ decrease in WDPT from water treatment on seven sands (range of $38 \%$ to $91 \%$ decrease) and a $99 \%$ reduction for the one clay loam soil. Moore et al. (2010) noted that one field-based method to minimize SWR severity is frequent irrigation to avoid soil drying; but this can interfere with site use, increases water use, and is often not effective. In a review of SWR reduction and water adsorption, Doerr et al. (2000) suggested that more frequent water application could: 1) weaken the soil-organic matter molecule bonds and increase displacement of organic molecules; or 2) result in enhanced dissolution of surface active organics and reduction of soil water surface tension/wettability.

Evaluation of enzymes for alleviation of water-repellent soil. The ANOVA for each soil revealed significant enzyme and dosage main effects and interactions (Table 3 ). After treatment for $3 \mathrm{~d}$ followed by drying at $40{ }^{\circ} \mathrm{C}$ for $36 \mathrm{~h}$, only the high dosage of chitinase, laccase, pectinase, and protease was effective in reducing WDPT less than $60 \mathrm{~s}$ for the very strongly hydrophobic LDS Soil 7. For the strongly hydrophobic fairy ring Soil 21 , the medium and high dosage of chitinase, laccase, and pectinase as well as the high dosage of $\alpha$-amylase resulted in WDPTs less than 60 .

The remaining enzymes demonstrated various effects on SWR (Table 3). Esterase on both soils resulted in increased WDPT as dosage increased. For several enzymes, the low or medium enzyme dosage caused WDPT to increase but then to decline at the high dosage for Soil 7 (cellulase, $\beta$-glucosidase, and xylanase) and for Soil $21(\alpha$-amylase and $\beta$-glucosidase). Lipase appeared to have little effect on WDPTs.

To our knowledge, Liu et al. (2013b) were the first report of direct enzyme application for treatment of SWR; and they demonstrated a high degree of SWR remediation with a

Table 3. Water drop penetration time (WDPT, s) on two soils, treated with 10 enzymes at three dosage rates for 3 -d incubation followed by drying at $40{ }^{\circ} \mathrm{C}$ for $36 \mathrm{~h}$ and then WDPT determination. ${ }^{\mathrm{z}}$

\begin{tabular}{|c|c|c|c|c|c|c|c|c|c|}
\hline \multicolumn{4}{|c|}{ Treatments } & \multicolumn{3}{|c|}{ Soil 7} & \multicolumn{3}{|c|}{ Soil 21} \\
\hline \multirow[b]{3}{*}{ Enzyme } & \multicolumn{3}{|c|}{ Enzyme Dosage } & \multicolumn{3}{|c|}{ Dosage } & \multicolumn{3}{|c|}{ Dosage } \\
\hline & Low & Medium & High & Low & Medium & High & Low & Medium & High \\
\hline & \multicolumn{3}{|c|}{ U/g soil } & \multicolumn{6}{|c|}{$\mathrm{WDPT}^{\mathrm{y}}(\mathrm{s})$} \\
\hline$\overline{\alpha \text {-Amylase }}$ & 4.5 & 45 & 450 & 342 & 336 & 272 & 261 & 301 & 56 \\
\hline Cellulase & 3 & 15 & 75 & 399 & 255 & 169 & 128 & 123 & 106 \\
\hline Chitinase & 0.0011 & 0.011 & 0.111 & 220 & 151 & 21 & 71 & 35 & 1 \\
\hline Esterase & 0.255 & 2.55 & 25.5 & 321 & 425 & 501 & 113 & 143 & 223 \\
\hline B-Glucosidase & 0.03 & 0.3 & 3 & 408 & 366 & 312 & 166 & 181 & 138 \\
\hline Laccase & 0.08 & 0.8 & 8.0 & 311 & 242 & 23 & 73 & 35 & 3 \\
\hline Lipase & 0.0027 & 0.027 & 0.27 & 359 & 350 & 340 & 117 & 121 & 135 \\
\hline Pectinase & 0.156 & 1.56 & 15.6 & 354 & 171 & 44 & 70 & 53 & 2 \\
\hline Protease & 0.375 & 3.75 & 37.5 & 314 & 203 & 43 & 106 & 183 & 2 \\
\hline Xylanase & 0.375 & 3.75 & 37.5 & 415 & 429 & 257 & 95 & 111 & 153 \\
\hline Water & - & - & - & \multicolumn{3}{|c|}{338} & \multicolumn{3}{|c|}{133} \\
\hline \multicolumn{4}{|c|}{ Fisher's LSD $(P<0.01)$ (enzyme) } & \multicolumn{3}{|c|}{16} & \multicolumn{3}{|c|}{12} \\
\hline \multicolumn{4}{|c|}{ Fisher's LSD $(P<0.01)$ (dose) } & \multicolumn{3}{|c|}{9} & \multicolumn{3}{|c|}{7} \\
\hline \multicolumn{4}{|c|}{ Fisher's LSD $(P<0.01)($ enzyme $\times$ dose $)$} & \multicolumn{3}{|c|}{27} & \multicolumn{3}{|c|}{21} \\
\hline
\end{tabular}

${ }^{z}$ Treatment with water alone for both soils is included for comparison under the same conditions.

${ }^{\mathrm{y}}$ WDPT classes: less than $5 \mathrm{~s}$ penetration time as very hydrophilic soil; 5 to $60 \mathrm{~s}$ hydrophilic; 60 to $180 \mathrm{~s}$ slightly hydrophobic; 180 to $600 \mathrm{~s}$ moderately hydrophobic; 600 to $3600 \mathrm{~s}$ strongly hydrophobic; 1 to $5 \mathrm{~h}$ very strongly hydrophobic; and greater than $5 \mathrm{~h}$ as extremely hydrophobic (Doerr, 1998 ). LSD $=$ least significant difference. 
combination of ligninolytic enzymes (primarily laccase with small quantities of lignin peroxidase, manganese peroxidase) and a low level of $\beta$-glucosidase, a hydrolytic enzyme. Our results indicate that chitinase, pectinase, and protease also have potential to alleviate SWR as well as confirming the effectiveness of laccase to reduce SWR.

Because we observed alleviation of SWR with several enzymes, this suggests that the organic matter associated with SWR in these soils from turfgrass sites may be diverse in nature. Laccase is an enzyme active on complex organic matter such as lignin and it has a high capacity for non-specific oxidation of various aromatic and non-aromatic compounds (Sidhu et al., 2013). The remaining effective enzymes are more specific such as: 1) chitinase, a hydrolytic enzyme that degrades glycosidic bonds in chitin found in fungi but also in some plant tissues; 2) protease, a hydrolytic enzyme of peptide bonds linking amino acids in proteins; and 3) pectinase, a hydrolytic enzyme that degrades pectin, a polysaccharide found in plant cell walls.

Liu et al. (2013b) suggested that possible mechanisms for direct application of enzymes to remediate SWR may be: 1) decomposition or degradation of organic matter coating associated with SWR similar to the findings of Sidhu et al. $(2012,2013)$ where applied laccase induced decomposition of organic matter in thatch/mat studies; or 2) alteration of the hydrophobic-hydrophilic characteristics of the organic matter to reduce SWR as noted by Horne and McIntosh (2000) in their paper concerning proposed mechanisms of repellency expression.

In reviewing bioremediation methods to control SWR, Müller and Deurer (2011) noted research primarily by Roper (2004, 2006, 2007) who evaluated various actinobacteria for effects on SWR in laboratory and field studies. Roper (2007) distinguished two general types of wax-degrading bacteria, listed bacteria species within each group, and discussed possible mode of action. The two classes were: 1) bacteria with hydrophobic cell surfaces that may directly degrade wax coating associated with SWR; and 2) bacteria that produced biosurfactants. Inoculation of water-repellent soils in the field with waxdegrading bacteria resulted in some reduction of SWR, but effectiveness was noted as being limited compared with bacteria production costs (Roper, 2006). Enhanced cultural practices, especially liming, to favor bacteria activity were more effective than continued inoculation (Roper, 2006). Response from wax-degrading bacteria would suggest that lipase may be involved as an active enzyme; however, we did not observe any activity from applied lipase. The difference in observation could be the result of the nature of the organic fractions contributing to SWR, which can vary with species of plants on the site (Atanassova and Doerr, 2010).

Similar to the studies by Roper (2004, 2006, 2007), research on enzymes in soils have concentrated on practices to increase particular microorganism populations through inoculation or cultural methods to enhance enzyme levels from microbial extracellular origin. For example, review of laccase soil activity by Henry (2012) and Sinsabaugh (2010) were all related to extracellular enzymes sources. Our interest in evaluation of direct enzyme treatment for SWR was initially based on the effectiveness of fungal laccase application to control excessive organic matter in turfgrass ecosystems in contrast to unsuccessful direct microbial inoculation and difficulties in maintaining microbial populations in the field discussed by Sidhu et al. (2012, 2013). The positive results from ligninolytic enzyme application on soils to alleviate SWR in laboratory studies suggested that other enzymes should be evaluated because organic matter associated with hydrophobic conditions can be diverse in nature.

For those enzymes that were effective in reducing WDPT to less than $60 \mathrm{~s}$, we evaluated the WDPT vs. enzyme dosage relationship (Table 4). Regression analysis revealed a significant exponential relationship for chitinase, laccase, pectinase, and protease on Soil 7 with a $R^{2}$ range of 0.87 to 0.98 . Exponential relationships were also noted on Soil 21 for laccase, pectinase, and protease $\left(R^{2}\right.$ range 0.93 to 0.97 ), whereas a logarithmic relationship at $R^{2}=0.93$ occurred for chitinase and a polynomial response for $\alpha$-amylase at $R^{2}=0.74$. When evaluating seven hydrophobic sands to applied laccase rates for effect on WDPT, Liu et al. (2013b) reported significant exponential responses for four sands and logarithmic relations on three sands.

Because Liu et al. (2013b) had reported residual activity of laccase, we also evaluated residual laccase activity in the liquid filtrates

Table 4. WDPT (water droplet penetration time, s) response relationship to applied enzyme dosage for top four/five enzymes in each soil that exhibited effective remediation of soil water repellency. ${ }^{2}$

\begin{tabular}{llrr}
\hline Soil & Enzyme & \multicolumn{1}{c}{ Relationship } & $R^{2}$ \\
\hline 7 & Chitinase & WDPT $=243.14 \mathrm{e}^{-22.17 \mathrm{x}}$ & 0.96 \\
7 & Laccase & WDPT $=324.68 \mathrm{e}^{-0.339 \mathrm{x}}$ & 0.98 \\
7 & Pectinase & WDPT $=291.25 \mathrm{e}^{-0.123 \mathrm{x}}$ & 0.87 \\
7 & Protease & WDPT $=299.24 \mathrm{e}^{-0.052 \mathrm{x}}$ & 0.97 \\
& & \\
21 & Chitinase & WDPT $=-13.81 \mathrm{n}(\mathrm{x})-22.64$ & 0.93 \\
21 & Laccase & WDPT $=80.446 \mathrm{e}^{-0.436 \mathrm{x}}$ & 0.93 \\
21 & Pectinase & WDPT $=90.146 \mathrm{e}^{-0.234 \mathrm{x}}$ & 0.97 \\
21 & Protease & WDPT $=154.37 \mathrm{e}^{-0.114 \mathrm{x}}$ & 0.95 \\
21 & $\alpha$-Amylase & WDPT $=-0.0074 \mathrm{x}^{2}+3.023 \mathrm{x}+186.87$ & 0.74 \\
\hline${ }^{\mathrm{z}} R^{2}=$ coefficient of determination; $\mathrm{x}=$ enzyme dosage in activity units presented in Table 3 for each \\
enzyme.
\end{tabular}

in the first study at $3 \mathrm{~d}$ after enzyme treatment. However, residual activity of the other enzymes in our study was not determined. Residual activity of laccase ranged from $44 \%$ to $84 \%$ for Soil 7 (Fig. 1) and $72 \%$ to $93 \%$ for Soil 21 (Fig. 2). On three soils, including Soil 7 used in this study, Liu et al. (2013b) reported laccase residual activities from $16 \%$ to $54 \%$ after 1 - to 5 -d incubations and extraction of the filtrate. Residual activity was slightly higher on the first day. Presence of residual enzyme activity suggests enzyme stability, which could influence frequency of application in field situations.

Response of the most effective enzymes using a 1-d incubation period. To verify the results of the first experiment, the most effective enzymes were applied to the same two soils at the high dosage rate along with a water control (Table 5). However, a shorter incubation period of $1 \mathrm{~d}$ was used based on the observation of Liu et al. (2013b) that for laccase incubation of $1 \mathrm{~d}$ resulted in similar results as a 3-d incubation. All other experimental conditions were similar between the first and second enzyme type experiments. Incubation at $1 \mathrm{~d}$ with water resulted in WDPT of 332 (moderately hydrophobic by the scale of Doerr, 1998) and 94 s (slightly hydrophobic) for Soils 7 and 21, respectively. All enzymes at the high dosage exhibited WDPT less than $60 \mathrm{~s}$ on both soils except for pectinase on Soil 7 that had a WDPT of $135 \mathrm{~s}$ after $1-\mathrm{d}$ incubation. Pectinase applied to Soil 21 had higher WDPT at $1 \mathrm{~d}$ than in the first study, which may suggest that pectinase may require

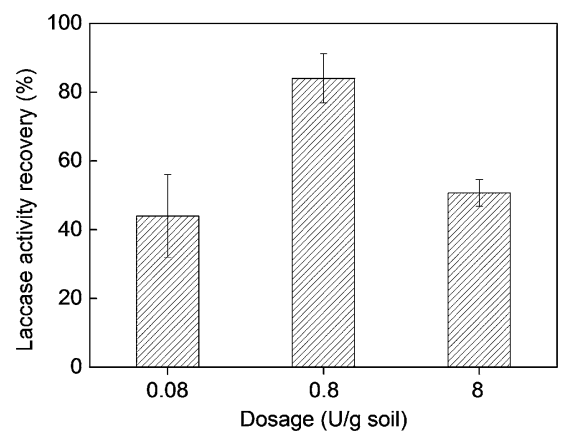

Fig. 1. Laccase activity recovery in liquid filtrate after treatment of Soil 7 at various laccase dosages for 3-d incubation.

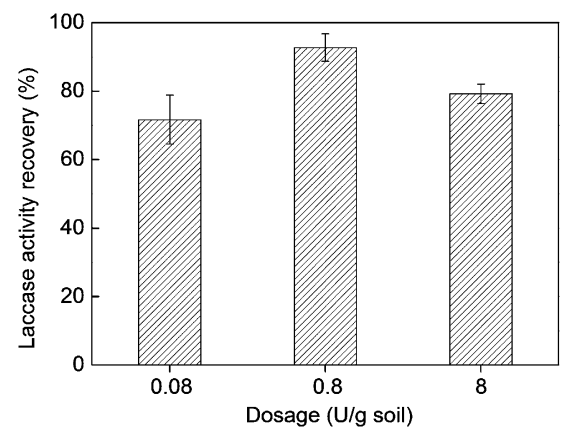

Fig. 2. Laccase activity recovery in liquid filtrate after treatment of Soil 21 at various laccase dosages for 3-d incubation. 
Table 5. Influence of four enzymes and water control on water drop penetration time (WDPT, s) applied at the high rate (highest rate used in the studies in this article) and incubated for $1 \mathrm{~d}$.

\begin{tabular}{|c|c|c|c|}
\hline \multirow[b]{2}{*}{ Treatment } & \multirow{2}{*}{$\begin{array}{c}\text { Rate } \\
\text { U/g soil }\end{array}$} & Soil 7 & Soil 21 \\
\hline & & \multicolumn{2}{|c|}{$\begin{array}{l}\text { WDPT }(\mathrm{s}) \\
\end{array}$} \\
\hline Untreated & - & 7440 & 665 \\
\hline Control, water & - & 332 & 94 \\
\hline Chitinase & 0.111 & 19 & 1 \\
\hline Laccase & 8.0 & 13 & 1 \\
\hline Pectinase & 15.6 & 135 & 46 \\
\hline Protease & 37.5 & 48 & 5 \\
\hline Fisher's LSD & & 5.9 & 9.5 \\
\hline
\end{tabular}

${ }^{\mathrm{z}}$ Means compared by Fisher's protected least significant difference (LSD) test.

longer periods to be effective in SWR situations than laccase, chitinase, and protease.

\section{Conclusions}

This is the first report of the effectiveness of direct application of specific enzymes (chitinase, pectinase, protease) to remediate SWR at the laboratory scale; and our results confirm the ability of laccase application for alleviation of SWR as first reported by Liu et al. (2013b). On a very strongly hydrophobic soil (Soil 7) with a WDPT of $7440 \mathrm{~s}$ collected from a localized dry spot area on turfgrass, in both 1- and 3-d incubation studies, the high dosage rate of laccase, chitinase, and protease resulted in WDPT of less than $60 \mathrm{~s}$ (classified as hydrophilic by Doerr, 1998). Pectinase exhibited similar results in the $3-d$ incubation study but was less effective in the 1-d incubation experiment. On the strongly hydrophobic soil (Soil 21) collected from the dry area of a fairy ring with a WDPT of $655 \mathrm{~s}$, the high dosage of chitinase, laccase, pectinase, and protease in both studies demonstrated WDPT less than $60 \mathrm{~s}$; and medium dosage rates were also effective for all but protease on this soil in the 3 -d incubation study. Deionized water treatment reduced the degree of hydrophobicity in both soils to WDPTs of 332 to 338 (moderately hydrophobic, Soil 7) and 94 to 133 s (slightly hydrophobic, Soil 21). The four most effective enzymes for reducing WDPT demonstrated a significant exponential or logarithmic relationship between decreasing WDPT and increasing enzyme dosage. In a substudy of the 3 -d incubation experiment, we confirmed the findings of Liu et al. (2013b) that laccase maintains a high residual activity in the filtrate after $3 \mathrm{~d}$. These results suggest that direct application of selected enzymes to SWR soils may be a new option for alleviation of SWR, which could be significant because current practices are of limited effectiveness (Moore et al., 2010; Müller and Deurer, 2011). Further studies will be required to determine field efficacy, economics, and mechanisms of enzyme activity on SWR sands and water relationships. Sidhu et al. (2013) have not observed any adverse response of turfgrass plants to lacasse enzyme treatment, but other enzymes have not been evaluated for influence on turfgrass quality.

\section{Literature Cited}

Atanassova, I. and S. Doerr. 2010. Organic compounds of different extractability in total solvent extracts from soils of contrasting water repellency. Eur. J. Soil Sci. 61:298-313.

Bailey, T.G., N.J. Davidson, and D.C. Close. 2012. Understanding the regeneration niche: Microsite attributes and recruitment of eucalypts in dry forests. For. Ecol. Mgt. 269:229-238.

Barton, L. and T.D. Colmer. 2011. Ameliorating water repellency under turfgrass of contrasting soil organic matter content: Effect of wetting agent formulation and application frequency. Agr. Water Mgt. 99:1-7.

Blanco-Canqui, H. 2011. Does no-till farming induce water repellency to soils? Soil Use Mgt. 27:2-9.

Dekker, L.W., K. Oostindie, and C.J. Ritsema. 2005 Exponential increase of publications related to soil water repellency. Soil Res. 43:403-441.

Doerr, S.H. 1998. On standardizing the "water drop penetration time' and the 'molarity of an ethanol droplet' techniques to classify soil hydrophobicity: A case study using medium textured soils. Earth Surf. Process. Landf. 23:663-668.

Doerr, S.H., R.A. Shakesby, and R.P.D. Walsh. 2000. Soil water repellency: Its causes, characteristics and hydro-geomorphological significance. Earth Sci. Rev. 51:33-65.

Doerr, S.H., C.T. Llewellyn, P. Douglas, C.P. Morley, K.A. Mainwaring, C. Haskins, L. Johnsey, C.J. Ritsema, F. Stagnitti, G. Allinson, A.J.D. Ferreira, J.J. Keizer, A.K. Ziogas, and J. Diamantis. 2005. Extraction of compounds with water repellency in sandy soils of different origin. Aust. J. Soil Res. 43:225-237.

Fidanza, M.A., J.L. Cisar, S.J. Kostka, J.S. Gregos, M.J. Schlossberg, and M. Franklin. 2007. Preliminary investigation of soil chemical and physical properties associated with type-I fairy ring symptoms in turfgrass. Hydrol. Processes 21:2285-2290.

Franco, C.M.M., M.E. Tate, and J.M. Oades. 1995. Studies on non-wetting sands. I. The role of intrinsic particulate organic matter in the development of water-repellency in non-wetting sands. Aust. J. Soil Res. 33:253-263.

Henry, H.A.L. 2012. Soil extracellular enzyme dynamics in a changing world. Soil Biol. Biochem. 56:53-59.

Horne, D.J. and J.C. McIntosh. 2000. Hydrophobic compounds in sands in New ZealandExtraction, characterisation and proposed mechanisms for repellency expression. J. Hydrol. (Amst.) 231-232:35-46.
Liu, J., Y. Cai, X. Liao, Q. Huang, Z. Hao, M. Hu, D. Zhang, and Z. Li. 2013a. Efficiency of laccase production in a $65-\mathrm{L}$ air-lift reactor for potential green industrial and environmental application. J. Clean. Prod. 39:154-160.

Liu, J., L. Zeng, R.N. Carrow, P.L. Raymer, and Q. Huang. 2013b. A novel approach for alleviation of soil water repellency using a crude enzyme extract from fungal pretreatment of switchgrass. Soil Res. 51:322-329.

Microsoft. 2013. Microsoft Excel 2010 data analysis. Microsoft, Redmond, WA.

Moore, D., S.J. Kostka, T.J. Boerth, M. Franklin, C.J. Ritsema, L.W. Dekker, K. Oostindie, C. Stoof, and J. Wesseling. 2010. The effect of soil surfactants on soil hydrological behavior, the plant growth environment, irrigation efficiency and water conservation. J. of Hydrology and Hydromechanics 58:142-148.

Müller, K. and M. Deurer. 2011. Review of the remediation strategies for soil water repellency. Agr. Ecosyst. Environ. 144:208-221.

Nadav, I., J. Tarchitzky, A. Lowengart-Aycicegi, and Y. Chen. 2011. Soil surface water repellency induced by treated wastewater irrigation: Physio-chemical characterization and quantification. Irrig. Sci. 31:49-58.

Park, J.W., J. Dec, J.E. Kim, and J.M. Bollag. 1999. Effect of humic constituents on the transformation of chlorinated phenols and anilines in the presence of oxidoreductive enzymes or birnessite. Environ. Sci. Technol. 33:2028-2034.

Rillig, M.C. 2005. A connection between fungal hydrophobins and soil water repellency? Pedobiologia (Jena) 49:395-399.

Roper, M. 2006. Potential for remediation of water repellent soils by inoculation with wax-degrading bacteria in south-western Australia. Biologia 61:S358-S362.

Roper, M.M. 2004. The isolation and characterisation of bacteria with the potential to degrade waxes that cause water repellency in sandy soils. Aust. J. Soil Res. 42:427-434.

Roper, M.M. 2005. Managing soils to enhance the potential for bioremediation of water repellency. Soil Res. 43:803-810.

Roper, M.M. 2007. Microorganisms - Cause or remediators of water repellency? Proc. Bouyoucos Conference on the Origin of Water Repellency in Soils, Florida, 29 Apr. to 3 May 2007. Abstract 10. p. 56

SAS Institute Inc. 1994. The SAS system for Windows. Release 9.2. SAS Institute, Cary, NC.

Sidhu, S.S., Q. Huang, R.N. Carrow, and P.L. Raymer. 2012. Use of fungal laccase to facilitiate biodethatching: A novel approach. HortScience 47:1-7.

Sidhu, S.S., Q. Huang, R.N. Carrow, and P.L. Raymer. 2013. Laccase mediated changes in physical and chemical composition properties of thatch layer in creeping bentgrass (Agrostis stolonifera L). Soil Biol. Biochem. 64:48-56.

Sinsabaugh, R.L. 2010. Phenol oxidase, peroxidase and organic matter dynamics of soil. Soil Biology and Biochemistry 42:391-404. 